\title{
A psoriasis kezelése során alkalmazott harkányi balneoterápia és a hüvely ökológiai egyensúlya*
}

\section{Vaginal ecological balance during hydrotherapy of psoriatic patients with Harkany medicinal spa water}

\author{
VARGA PÉTER DR., HETESI CSILLA, MALMER NAGYEZSDA DR., \\ JAGICZA ANNA DR., PÉTER IVÁN DR. \\ Zsigmondy Vilmos Harkányi Gyógyfürdőkórház \\ Nonprofit Kft., Harkány
}

\section{ÖSSZEFOGLALÁS}

A szerzók a psoriasis fellángolásában, más egyéb tényezö között szerepet játszó kóros hüvelyflóra esetleges kialakulását vizsgálták a psoriasis kezelésében a speciális összetételü, carbonyl-sulfid, hydrogen-sulfid tartalmú harkányi gyógyvíz alkalmazásával történó fürdőkezelések után.

Arra a kérdésre kívántak választ kapni, hogy a harkányi forrásvízzel végzett fürdökúra eredményez-e a hüvely vegyhatásában is megnyilvánuló ökológiai változást. Ezzel együtt: kimutatható-e a kóros hüvely flórát (hüvelyi pH>4,5) mutató esetek arányának növekedése a fürdókúra során?

250 beteg harkányi gyógyvízzel történő gyógykezelése során a hüvely $\mathrm{pH}$ protokoll szerinti rendszeres, hüvelyi pH tesztcsíkkal történt mérésével követték a hüvely ökológiájának esetleges módosulását. A három mérésre a kezelések megkezdése elött (I.), a háromhetes, 9-14 alkalommal (átlag: 12,3 \pm 3,6) történt 34-35 Celsius fokos, 25 perces, másnaponta alkalmazott gyógyvizes kádfürdő kezelést követően (II.), valamint a 3 hónappal késóbbi ellenörző vizsgálat során (III.) került sor.

A kezelés megkezdésekor (I.) a hüvely átlagos pH értéke: 4,77 (₫0,572) volt. Ez a fürdókúra befejezése után (II. mérési pont) csökkent, de a csökkenés nem volt szignifikáns mértékü, a hüvelyi pH: 4,59 (£0,635). Jelentôs változást a 3 hónapos kontroll során (III. mérési pont) sem észleltek: pH: 4,62 ( $\pm 0,457)$. A felvételkor magukat panaszmentesnek tartó nôk 47, 2\%-ánál (n=118) észleltek kóros pH tartományba $(\mathrm{pH}>4,5)$ esố hüvelyi $\mathrm{pH}$ értéket. Ez a kezeléseket követöen 32,8\%-ra (n=82) esett vissza, a késói, a 3 hónappal késóbbi ellenórző vizsgálat már csak 28\%-uknál (70 eset) jelzett kóros hüvelyi ökológiai állapotra utaló $\mathrm{pH}$ eltérést.

\footnotetext{
* szponzorált közlemény
}

\section{SUMMARY}

Vaginal infection is known to provoke symptoms of psoriasis. Unfavorable changes in vaginal ecology (dysbacteriosis) are frequently suspected to be in association with prior thermal bath hydrotherapy treatments. Vaginal $\mathrm{pH}$ is a good indicator of vaginal bacterial flora. In normal vaginal ecological balance its value is expected to be lower than 4,5. The hydrogen sulphide containing Harkány spa medicinal hydrotherapy (balneotherapy) is a beneficial and frequently used application in easing psoriatic symptoms and recrudescence. In order to get information about the changes in vaginal bacterial flora during Harkany thermal spa water bath tub courses vaginal pH probes were performed and analyzed prior to and after spa therapy course of women in this study.

Vaginal pH values were measured and noted regularly by the means of special pH Test Strips in 250 included patients. Three sampling measures was taken in each patient: before (I) and after (II) the course, as well as during a final checkup examination taken after three-months following spa treatment (III). Hydrotherapy courses consisted of 9-14 occasions (mean: 12,3 $\pm 3,6$ ), each providing 20 to 25 minutes long tub-bath thermal medicinal water of 34-35 $C^{\circ}$ temperature applied every other day.

Prior to hydrotherapy (I.) the mean vaginal $\mathrm{pH}$ of patients was: 4,77 ( $\pm 0,572)$. This value decreased somewhat during the course of hydrotherapy. At the end of the set of treatments (II) the mean vaginal pH was lower: 4,59 ( $\pm 0,635)$ (II.). Nevertheless, this decrease in vaginal pH was not significant. There was no remarkable change after the 3 month' control examination (III), as well: $\mathrm{pH}: 4,62$ $( \pm 0,457)(I I I)$.

At the time of admission at 47,2\% (n=118) of all women, however presenting no symptoms or complaints, an inappropriate $\mathrm{pH}(>4,5)$ was recognized. During

Levelező szerző: Dr. Varga Péter, Zsigmondy Vilmos Harkányi Gyógyfürdőkórház NpKft., és PTE Szülészeti és Nőgyógyászati Klinika Mozgásszervi Rehabilitációs Osztály - Nőgyógyászati részleg, 7815 Harkány, Zsigmond Vilmos Sétány 1. e-mail: petervar@t-online.hu 
A kapott eredmények cáfolni látszanak azokat a feltételezéseket, miszerint a gyógyvíz és a gyógyvizes kúraszerü kezelés kiváltaná, vagy esetleg fokozná a normális hüvelyi baktériumflóra, ezzel annak ökológiai egyensúlya kóros megváltozását. Az alkalmazott harkányi forrásvízzel történt kádfürdö kezelés során nem volt észlelhető megváltozott hüvelyi baktérium flóra, dysbacteriosis, vagy éppen bacterialis vaginosis fokozott elöfordulása.

\section{Kulcsszavak: psoriasis - hüvely flóra - balneoterápia - kénes gyógyvíz}

hydrotherapy this indicator reduced to a 32,8\% (n=82) proportion of patients and at 3 months control it fell to $28 \%$ (70 out of all cases).

These testing data seem to disprove those presumptions which suspect unfavorable effects on vaginal ecological balance during hydrotherapy courses presumably by modifying normal vaginal flora. Sulphurous Harkány thermal spa medicinal water hydrotherapy does not enhance the unfavorable appearance of dysbacteriosis or bacterial vaginosis. Thus hydrotherapy of patients with sulphur containing thermal spa may not be a risk for psoriatic patients.

\section{Key words: \\ psoriasis - vaginal flora - hydrotherapy - sulphur spa - medicinal water}

A psoriasis, más néven pikkelysömör a nyugat-európai populáció 2-5\%-át érintő krónikus gyulladásos betegség, ami a bőrt és az ízületeket is érinti. Jellemző, hogy a tünetes és tünetmentes periódusok váltják egymást. Kialakulását és lefolyását genetikai hajlam és környezeti faktorok egyaránt befolyásolják. A betegség fellángolásában jelentős szerepe van az immunrendszer állapotának, illetve a különböző krónikus infekciók, így például krónikus hüvelygyulladások fennállásának, a hüvelyi normális baktérium flóra kóros eltérésének, a hüvelyi dysbacteriosisnak is. A psoriasis kezelése során figyelembe kell venni, hogy jelenleg gyógyítani nem tudjuk, csak kezelni, élethosszig tart, ezért a kezelések hosszú távú toxicitására, a teratogenitásra is figyelemmel kell lenni. Ezért a legkülönbözőbb szisztémás és biológiai kezelésfajták, valamint lokális kenôcsös, illetve fénykezelési típusok mellett kiemelt jelentősséggel bírnak a világ egyes kitüntetett adottságú helyein a különböző kémiai összetételû́ gyógyvizekkel történő, ún. „balneoterápiás” fürdőkezelések. Így jól ismert önmagában a tenger+napfény, a Holt tenger sós vizének + UVA fénykezelésnek kitûnố terápiás hatásai mellett a speciális összetételû, carbonyl-sulfid, hydrogen-sulfid tartalmú harkányi gyógyvíz alkalmazásával elérhető hatás e betegek körében.

A balneoterápiával kiegészített kezelés során kórházunkban az egyéb, fóleg lokális kezelések mellett a betegek napi 2 alkalommal gyógyvizes kád, vagy medencefürdô formájában részesülnek a balneoterápiában.

A hüvelygyulladásoknak a pikkelysömör fellángolásában játszott szerepe mellett gyakran felmerülő gyanú a gyógyvizes fürdőkezelésekkel szemben, hogy ezek következményeként hüvelyi gyulladás kialakulása, a hüvelyi ökológia kóros elváltozása következhet be.

A hüvely baktérium flórája és a hüvelyi pH meghatározza a hüvely ökológiai állapotát. Ez egy kényes dinamikus egyensúly - a hüvelyi flórát a reproduktív életszakasz legnagyobb részében több mint 100 féle mikroba, köztük aerob és anaerob baktériumok, gombafélék, stb. állandóan változó, dinamikus szimbiózisa alkotja (1).
Legfontosabb és egyben domináns alkotóelemét az antimikrobás hatású, tejsav termelő lactobacillusok képezik (Döderlein flóra). Ezek gátolják más hüvelyi mikrobák túlszaporodását. A lactobacillusok által termelt tejsav egyben meghatározza a hüvely pH-ját, annak enyhén savas vegyhatását. Normál hüvely flóra mellett a hüvelyi pH általában 3,8-4,5 között mérhetô.

Normális hüvelyi $\mathrm{pH}(\mathrm{pH}<4,5)$ mellett előfordulhat hüvelyi mycosis (candidiasis) is, de ilyenkor a klinikai kép, a fehér túrós, szagtalan fluor, mikroszkóposan látható sarjadzó gomba sejtek, pszeudohifák, a beteg által panaszolt égő-viszkető érzés segít a normális állapottól való elkülönítésben (2).

Kóros hüvely flórára utal, ha a hüvelyi $\mathrm{pH}>4,5$.

Ez a jellemzô az alábbi, a leggyakoribb kórokozók által okozott hüvelygyulladások esetén:

a. Bakteriális vaginózis (kórokozó: vegyes anaerob baktériumflóra, Gardnerella vaginalis, Mobiluncus species és Atopobium vaginae dominanciával): kenőcsös, homogén, tört fehér fluor, ,halszagú” kellemetlen váladék, nem fáj, mikroszkópos festett kenetben: „Clue” sejtek = a diagnózis „,kulcsát” jelentő baktériummal fedett laphámsejtek, lactoflóra és fehérvérsejtek hiánya.

b. Trichomoniasis (kórokozó: Trichomonas vaginalis): bő habos, zöldes sárgás, égô viszketô folyás, natív mikroszkópos képen: jellegzetes formájú és mozgású protozoonok, leukocyták.

c. Egyéb baktériumok okozta fertózések: a hüvelyflóra egyes tagjainak túlszaporodása, vagy külső fertôzésből származó baktériumok okozzák. A kórokozótól függően bôvebb sárgás, vagy vízszerú fluor, festett mikroszkópos keneten: leukocyták, gram pozitívan vagy negatívan festődố coccusok vagy pálcák a baktériumokra jellemző kép. Valódi sejtfal nélküli baktériumok (Ureaplasma, Mycoplasma, Chlamydia) esetén csak a leukocyták láthatóak. Esetleg társuló méhnyak gyulladás mellett a méhszájból ürülő bô váladék és a méhnyak hámjának ráterjedése a portiora (cervikalizáció). 


\begin{tabular}{|c|c|c|c|c|c|c|c|c|}
\hline & Normál & $\begin{array}{l}\text { Bacterialis } \\
\text { vaginosis }\end{array}$ & Candidiasis & Trichomoniasis & $\begin{array}{l}\text { Atrophiás } \\
\text { vaginitis }\end{array}$ & $\begin{array}{l}\text { Valódi } \\
\text { sejtfalú } \\
\text { baktérium } \\
\text { okozta colpitis }\end{array}$ & $\begin{array}{l}\text { Valódi } \\
\text { sejtfal } \\
\text { nélküli } \\
\text { baktérium } \\
\text { okozta } \\
\text { colpitis }\end{array}$ & $\begin{array}{l}\text { Citolítikus } \\
\text { vaginosis }\end{array}$ \\
\hline Tünetek & Nincs & $\begin{array}{l}\text { Bővebb } \\
\text { folyás, } \\
\text { kellemetlen } \\
\text { (hal-) szag }\end{array}$ & $\begin{array}{l}\text { Égés, } \\
\text { viszketés }\end{array}$ & $\begin{array}{l}\text { Égés, } \\
\text { viszketés } \\
\text { kellemetlen } \\
\text { szag }\end{array}$ & $\begin{array}{l}\text { Hüvely- } \\
\text { szárazság }\end{array}$ & $\begin{array}{l}\text { Bôvebb } \\
\text { folyás }\end{array}$ & $\begin{array}{l}\text { Bővebb } \\
\text { folyás }\end{array}$ & $\begin{array}{l}\text { Égô, csípő } \\
\text { hüvelyszárazság }\end{array}$ \\
\hline Folyás & $\begin{array}{l}\text { Fehér, } \\
\text { vagy } \\
\text { színtelen } \\
\end{array}$ & $\begin{array}{l}\text { Szürkésfehér, } \\
\text { tejszerû, } \\
\text { homogén }\end{array}$ & $\begin{array}{l}\text { Bő, fehér, } \\
\text { „túrós" }\end{array}$ & $\begin{array}{l}\text { Sárgászöldes, } \\
\text { habos }\end{array}$ & Vizes, híg & $\begin{array}{l}\text { Sárgás, } \\
\text { gennyes }\end{array}$ & $\begin{array}{l}\text { Vízszerū, } \\
\text { híg }\end{array}$ & $\begin{array}{l}\text { Színtelen, vérrel } \\
\text { festenyzett }\end{array}$ \\
\hline Hüvely pH & $3,8-4,2$ & $>4,5$ & $<4,5$ & $>4,5$ & $>5,0$ & $>4,5$ & $>4,5$ & $<3,8$ \\
\hline Amin teszt & Neg & Pozitív & Neg. & Pozitív & Neg. & Neg & Neg & $\mathrm{Neg}$ \\
\hline $\begin{array}{l}\text { Mikrosz- } \\
\text { kóp }\end{array}$ & $\begin{array}{l}\text { Lacto } \\
\text { bacilusok, } \\
\text { laphám- } \\
\text { sejtek }\end{array}$ & $\begin{array}{l}\text { „Kulcs” } \\
\text { (clue) sejtek } \\
\text { (fehérvér- } \\
\text { sejtek } \\
\text { hiányoznak!) }\end{array}$ & $\begin{array}{l}\text { Sarjadzó } \\
\text { gomba } \\
\text { sejtek, } \\
\text { pseudo- } \\
\text { hyphák }\end{array}$ & $\begin{array}{l}\text { Ostoros } \\
\text { egysejtűek, } \\
\text { fehérvér- } \\
\text { sejtek }\end{array}$ & $\begin{array}{l}\text { Paraba- } \\
\text { salis sejtek } \\
\text { (a lactoba- } \\
\text { cilusok } \\
\text { hiányoznak!) }\end{array}$ & $\begin{array}{l}\text { Fehérvér- } \\
\text { sejtek, } \\
\text { az adott } \\
\text { kórokozó } \\
\text { baktérium } \\
\text { dominanciája }\end{array}$ & $\begin{array}{l}\text { Fehérvér- } \\
\text { sejtek }\end{array}$ & $\begin{array}{l}\text { Lizált } \\
\text { laphám- } \\
\text { sejtek, } \\
\text { zsúfolva } \\
\text { lactoba- } \\
\text { cilusssal }\end{array}$ \\
\hline
\end{tabular}

1. táblázat

A hüvelyi infekciók differenciáldiagnosztikája/diagnosztikája (3)

d. Atrofiás hormonhiányos hüvelygyulladás: égő hüvelyszárazság, vérzékeny, sérülékeny, elvékonyodott hüvelyhám, vizes tiszta fluor, Lactobacillusok hiányoznak, parabasalis, basalis sejtek dominanciája.

A hüvelyi pH 3,8 alá is csökkenhet, a lactobacillusok túlzott elszaporodásával, citolítikus vaginosist okozva.

A hüvelyi fertôzések differenciáldiagnosztikája/diagnosztikája áttekinthetô formában az 1. sz. táblázatban látható (3).

Tekintettel arra, hogy a hüvelyfertőzésért felelős mikroorganizmusok egy része kis csíraszámban átlagos tenyésztési eljárással (aerob tenyésztés) 5-40\%-ban egészséges hüvelyváladékból is kitenyészthető, a hüvelyváladék tenyésztéses vizsgálata ezért csak a kenettel együtt értékelhető (4), ha a kenetben gyulladásos sejtek nincsenek, ezeket a baktériumokat nem tekintjük kórokozónak. Ugyanakkor a valódi sejtfallal nem rendelkező, speciális tenyésztési igényű kórokozók jelenlétére, bakteriális vaginosisra, citolítikus vaginosisra is a mikroszkópos kenet hívja fel a figyelmet.

\section{A hüvelyflórát befolyásoló tényezôk $(5,6)$}

- Pubertás

- Menstruáció - bakteriális vaginózis

- Ösztrogén hatás:a ciklus első felében -az anaerob baktériumok, a Bacteroidesek aránya nô.

- Progeszteron hatásra a ciklus második felében - az anaerob baktériumok aránya csökken, Lactobacillus arány nő

- Ösztrogén kezelés alatt a sarjadzó gombák aránya nô.

- Terhesség

- Szoptatás

- Antibiotikum kezelés - gombák, Enterococcusok

- Elhúzódó hüvelyi vérzés.

- Hüvelyi mútét után

- Menopauza
- Fokozott szexuális aktivitás

- Immunrendszer legyengülése, illetve betegsége.

- Gyakori irrigálás. - Fürdővizek?

\section{A vizsgálat célja}

Előzetes klinikai felmérésünk során arra a kérdésre kívántunk választ kapni, hogy a gyógyvízzel - esetünkben a harkányi forrásvízzel - végzett fürdőkúra eredményez-e a hüvely vegyhatásában is megnyilvánuló ökológiai változást? Ezzel együtt kimutatható-e a kóros hüvely flórát (hüvelyi pH>4,5) mutató esetek arányának növekedése a fürdőkúra során?

\section{Betegek és vizsgálati módszer}

250 beteg harkányi gyógyvízzel történő gyógykezelése során a nőgyógyászati vizsgálatokhoz kapcsolódóan a hüvely $\mathrm{pH}$ elôre megtervezett protokoll szerinti rendszeres mérésével követtük a hüvely ökológiájának esetleges módosulását.

A hüvelyi pH mérése a nôgyógyászati vizsgálat részeként alkalmazott egyszerú hüvelyi pH tesztcsíkkal (MERCK Lab., mérési tartomány: 3,6- 7,0) történt (7). A mérésre a standard ellátási protokollunk szerint három vizsgálati időpontban került sor: a kezelések megkezdése előtt (I.), a legalább háromhetes, 9-14 alkalommal (átlag: $12,3 \pm 3,6$ ) $20-25$ perces, $34-36{ }^{\circ} \mathrm{C}-\mathrm{os}$ gyógyvizes kádfürdő kezelés után (II.), valamint 3 hónappal késôbb az ellenőrző szakvizsgálat során (III.). A hüvelyi pH érték mellett a klinikai vizsgálati leletek (klinikai panaszok, inspekció, mikroszkópos natív és festett kenetvizsgálat, amin teszt, stb.) alapján mindenkor tisztáztuk, hogy fennáll-e esetleg bakteriális, gombás vagy protozoon által okozott hüvelyi gyulladás. A felvételkor akut hüvelyi gyulladás jeleit mutató betegeket a balneoterápiás kezelésból, így a vizsgálatból is eleve kizártuk (8). 


\section{Az alkalmazott kezelések}

- A vizsgált betegek a 21-28 napos kúra során alapbetegségeiknek (psoriasis, meddôség, endometriosis, krónikus kismedencei gyulladások, mútét utáni összenövések, perimenopausával összefüggô megbetegedések, stb.) megfelelő kezeléseiken kívül a harkányi kénes termálvizes kádfürdő kezeléseket kaptak: $34-36{ }^{\circ} \mathrm{C}, 20-25$ perc, másnaponta, összesen 9 14 kezelés. A vizsgálatban résztvevő betegek a balneoterápia során kizárólag kádfürdő kezelésben részesültek, medencefürdő, vagy egyéb „közös” vízhasználat lehetőségét kizártuk.

- A betegségeiknek megfelelően alkalmazott kiegészítô kezelések esetenként az alábbiak voltak:

- Másnaponta „iszapnadrág” pakolás - a kismedence körbegöngyölése hévizi iszap és harkányi gyógyvíz keverékével $\left(42{ }^{\circ} \mathrm{C}, 25\right.$ perc)

o Gyógymasszázs - alhas és gerinc (heti 2-szer 15 perc)

o Női (intim) torna: heti 3-szor 15 perc

\section{Eredmények}

A kezelés megkezdésekor (I.) a hüvely átlagos pH értéke: 4,77 $( \pm 0,572)$ volt. Ez a fürdőkúra befejezése után (II. mérési pont) csökkent, de a csökkenés nem volt szignifikáns mértékú, a hüvelyi pH: 4,59 ( $\pm 0,635)$. Jelentős változást a 3 hónapos kontroll során (III. mérési pont) sem észleltünk: pH: 4,62 ( $\pm 0,457)$ (1. ábra).

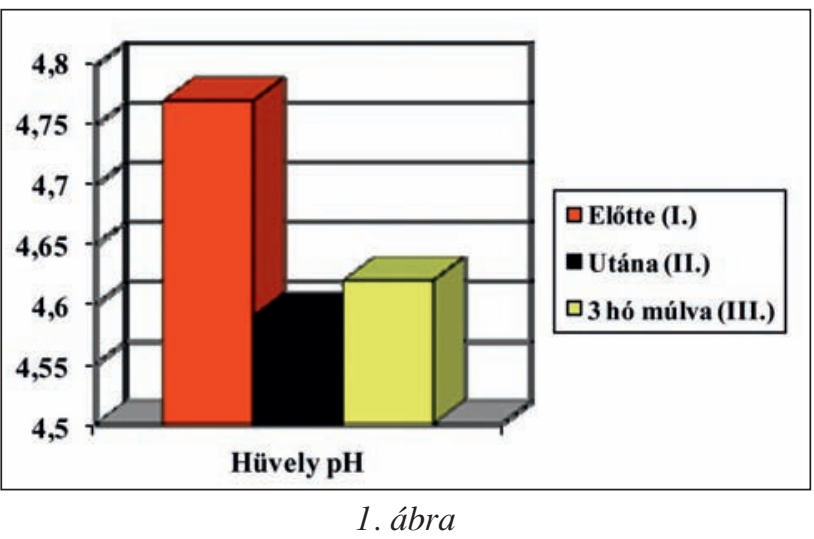

A hüvely pH változása a balneoterápiás kezelések során

A felvételkor magukat panaszmentesnek tartó nôk 47 , 2\%-ánál $(\mathrm{n}=118)$ észleltünk kóros $\mathrm{pH}$ tartományba ( $\mathrm{pH}>4,5)$ eső hüvelyi pH értéket. Ez a kezeléseket követôen 32,8\%-ra $(n=82)$ esett vissza, a késői, a 3 hónappal késôbbi ellenôrzô vizsgálat már csak 28\%-uknál (70 eset) jelzett kóros hüvelyi ökológiai állapotra utaló $\mathrm{pH}$ eltérést (2. ábra).

\section{Megbeszélés}

Felmérésünk eredménye cáfolni látszik azokat a feltételezéseket, miszerint a gyógyvíz és a gyógyvizes kúraszerú kezelés kiváltaná, vagy esetleg fokozná a normális hüvelyi baktériumflóra, ezzel az ökológiai egyensúly kóros megváltozását. Különösen fontos annak megállapítása, hogy az alkalmazott harkányi forrásvízzel történt kádfür-

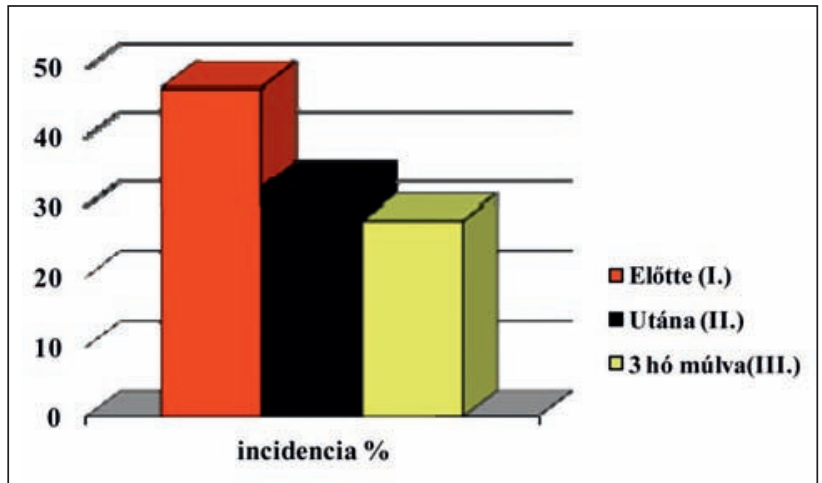

2. ábra

Kóros hüvelyi pH $(>4,5)$ incidenciája a balneoterápiában részesülő nôknél

dô kezelés során esetlegesen megváltozó hüvelyi baktérium flóra, dysbacteriosis, vagy éppen bacterialis vaginosis fokozott előfordulása nem volt észlelhetô. Nem jelentôs mértékben ugyan, de a kapott eredmények inkább a hüvelyflóra normális irányú változására utalnak a kénes (carbonylszulfidos) fürdő alkalmazása esetén. Eredményeink természetesen nem vonatkoztathatók a közös fürdőkben (medencefürdô kezelések, csoportos vizitorna, stb.), illetve más forrásokból nyert, a harkányitól eltérő összetételû́ gyógyvizekkel szerzett tapasztalatokra. Ennek ismerete fentebb tárgyalt oki tényezôk, illetve a következmények miatt fontos a psoriasis miatt harkányi gyógyvízzel kezelt betegek esetében is.

\section{A harkányi víz összetételének hatása}

Felmerülhet a kérdés, hogy a balneoterápia „,mellékhatásaként” a „köznyelvben” is megjelenő negatív megítélés, az idônként valóban tapasztalható hüvelyi irritációval, folyással járó panaszok mégis minek tudhatók be?

Már a harkányi kénes forrásvíz felfedezése és elsô kémiai elemzése óta jól ismert, hogy ez a víz igen gazdag ásványi anyag és ehhez társuló egyedülálló carbonylsulfid/ hydrogensulfid összetételénél fogva ,agresszív”, azaz nemcsak az emberi szöveteket, de még a legellenállóbb nemesacél fémkorlátokat, kapaszkodókat, vezetékeket is kimarja. A pikkelysömörös bőrelváltozásokra ennek köszönhetô pozitív hatása mellett ezeket a tulajdonságokat is érdemes figyelembe venni. A harkányi víz összetételét a 2. táblázat mutatja be.

A víz értékes hatóanyag tartalmával ezért szakmailag megfontoltan kell „gazdálkodni”, a túladagolás itt is veszélyt jelenthet. Nemcsak a belgyógyászok, kardiológusok által sokszor hangsúlyozott kardiovaszkuláris kockázatok, de a kémiai irritáció közvetlen a hüvelyhámot érintô veszélyei is óvatosságra intenek. A normális hüvely flóra, a gyógyvíz megfelelő, másnaponkénti legfeljebb 25-30 perces alkalmazása mellett, mint tapasztaltuk, nagyfokú védelmet és regeneráció képességet biztosít, az ökológiai változások nem jelentősek.

A kén (sulfidok) a legújabb feltételezések szerint hármas úton szívódnak fel: a korábbról jól ismert bőrön keresztüli (lásd pikkelysömör kezelés) felszívódás mellett a gáznemú, 


\begin{tabular}{|ll|}
\hline Nátrium & $\mathbf{1 5 0}$ \\
Ammónium & $\mathbf{1 , 5 3}$ \\
Kalcium & $\mathbf{5 1}$ \\
Magnézium & 15 \\
Vas & $\mathbf{0 , 0 5}$ \\
Kálium & $\mathbf{1 2 , 0}$ \\
Kationok összesen: & $\mathbf{2 3 0 , 1}$ \\
Klorid & $\mathbf{1 1 0}$ \\
Bromid & $\mathbf{0 , 3 2}$ \\
Jodid & $\mathbf{0 , 0 7}$ \\
Fluorid & $\mathbf{1 , 1 9}$ \\
Hidrogénkarbonát & $\mathbf{5 6 5}$ \\
Szulfid & $\underline{\mathbf{1 2 , 1}}$ \\
Össz. Foszfát & $\mathbf{0 , 1 6}$ \\
Anionok összesen: & $\mathbf{6 8 9}$ \\
Metabórsav & $\mathbf{6 , 6}$ \\
Metakovasav & $\mathbf{5 4}$ \\
Szabad kénsav & $\underline{170}$ \\
\hline
\end{tabular}

2. táblázat

A harkányi forrásvíz összetétele (1 liter vízben oldott ionok milligrammban megadott mennyisége) (9)

ismerten ,„penetráns” szagú hydrogensulfid számára a légutak jelentôs felszívó felülete, az oldott kénvegyületeknek pedig a hüvely hámja is megfelelő utat biztosít a keringésbe jutáshoz. Ez a számos tapasztalat és vizsgálat által értékelt igen komplex klinikai hatásokat váltják ki. Ezeket mindenek elôtt mozgásszervi, reumatológiai betegségek mellett fôleg psoriasissal összefüggő bőrgyógyászati és régóta jól ismerten, a krónikus kismedencei gyulladások, endometriosis, összenövések okozta, valamint számos más nôgyógyászati betegség rehabilitációs kezelése során tapasztaltuk (10). Ezzel együtt szem előtt kell tartanunk az egymástól függetlenül, különböző javallatok alapján elrendelt fürdőkezelések „halmozása” (pl. kád, medence, tangentor, iszap, stb.) által okozott nem kívánatos mellékhatások, így a hüvely kémiai irritációjának előfordulását is.

\section{Következtetések}

- A harkányi gyógyvizes kádfürdő kezelések (másnaponta 20-25') nem károsítják a hüvely vegyhatásá- nak $(\mathrm{pH})$ változásában mérhetô ökológiai egyensúlyt.

- A hüvelyfertôzések arányának növekedését nem lehet igazolni.

- Az esetenként észlelt szubjektív panaszok inkább kémiai irritáció következményei lehetnek, melyek a víz összetételével (carbonyl sulfid, hydrogen sulfid) függhetnek össze.

- A balneoterápiás kezelések gyakoriságának elrendelésénél (kád, medence, tangentor, stb.!) tanácsos figyelembe venni a hüvelyhámra és a hüvely ökológiájára kifejtett hatást is.

\section{IRODALOM}

1. Ravel J., Gajer P., Abdo Z., Schneider G. M., Koenig S. S, K., McCulle S. L., Karlebach S., Gorle R., Russell J., Tacket CO., Brotman R. M., Davis C. C., Ault K., Peralta L., Forney L. J.. Vaginal microbiome of reproductive-age women. The Arthur M. Sackler Colloquium of the National Academy of Sciences, "Microbes and Health" held November 2-3, 2009, at the Arnold and Mabel Beckman Center of the National Academies of Sciences and Engineering, Irvine, CA. http://www.nasonline.org/SACKLER_Microbes_and_Health.

2. Egan M., Lipsky M.: Diagnosis of Vaginitis. Am. Fam Physician. (2000) 62, 1095-1104.

3. Gardó Sándor: A hüvelygyulladások diagnosztikája és terápiája. Magyar Orvos. (2008) 43, 11. 21. 10:36:48

4. Egészségügyi Világszervezet. A szexuálisan átvihetô fertőzések kezelésének irányelvei. Infektológia és klinikai mikrobiológia. (2005) 12, 73-111.

5. Mashburn J.: Etiology, Diagnosis and Management of Vaginitis. Journal of Midwifery \&Women's Health. (2006) 51, 423-430.

6. Mitchell H.: Vaginal discharge-causes, diagnosis, and treatment. BMJ. (2004) 328, 1306-1308.

7. Sobel J.D.: Diagnostic approach to women with vaginal discharge or vulvovaginal symptoms. UpToDate Online. (2008) 16, 2.

8. Varga P., Malmer N.: A harkányi kénes termálvíz nőgyógyászati hatásainak összehasonlító klinikai vizsgálata. Balneológia, Gyógyfürdőügy, Gyógyidegenforgalom. (2009) 28, 13-37.

9. Emszt Kálmán: Harkányi hévforrások újabb chemiai elemzése. Hidr. Közl. VII-VIII. 1927-1928. p.96-100.

10. Varga P., Malmer N.: Gynaecological rehabilitation: recent experiences with sulphuric thermal spa water in Harkany, Hungary. La Presse Thermale et Climatique (2010) 147.

Érkezett: 2013. 09. 13.

Közlésre elfogadva: 2013. 10. 02.

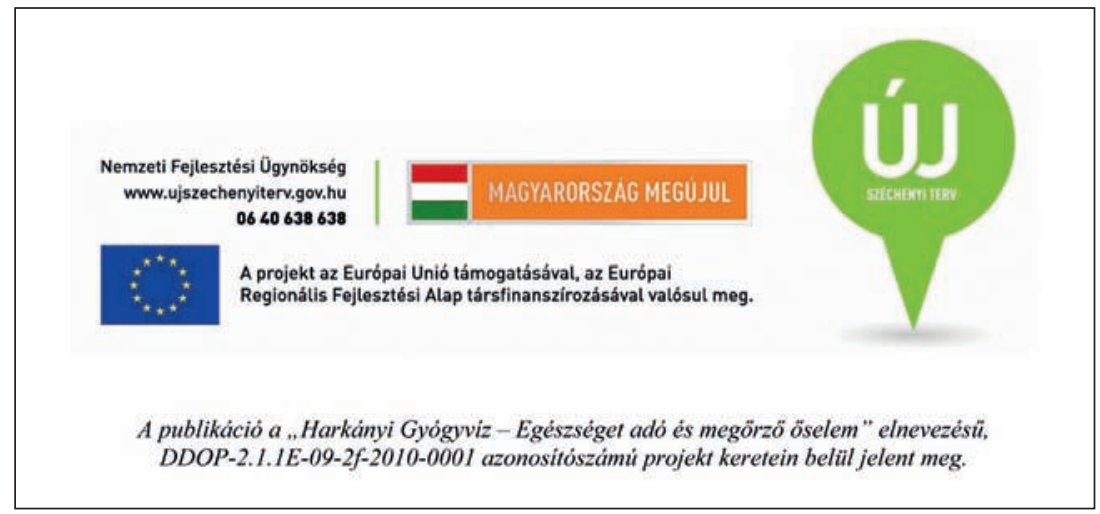

